Article

\title{
The Role of Institutional and Structural Differences for City-Specific Arrangements of Urban Migration Regimes
}

\author{
Eva Bund ${ }^{1, *}$ and Ulrike Gerhard ${ }^{2}$ \\ ${ }^{1}$ German Federal Office for Migration and Refugees, 90409 Nürnberg, Germany; E-Mail: eva.bund@bamf.bund.de \\ 2 Institute of Geography, Heidelberg University, 69120 Heidelberg, Germany; E-Mail: u.gerhard@uni-heidelberg.de \\ * Corresponding author
}

Submitted: 22 October 2020 | Accepted: 20 December 2020 | Published: 27 April 2021

\begin{abstract}
In recent years, an increasing influx of migrants to Europe has led to a heated public discourse about integration capacities within receiving countries such as Germany. During this period, German society, with its changeful immigration history, is again challenged to provide policy responses and foster migrant integration, especially in urban areas. The efforts of cities along that path, however, vary greatly. Complementing locality approaches on immigration and integration policies, which are focused on metropolises and the U.S.-American context, this article is an empirical application for understanding institutional and structural conditions for local variations in integration strategies in Germany by presenting a comparative analysis of four mid-sized cities. The particular research interest lies on discourses from interviews with local authorities and civil society actors. Our analysis reveals city-specific streamlines: For instance, discourses at a center of the 'knowledge society' focused on a strong municipal power structure that allowed communally-financed, sustainable projects to evolve from a historically-grounded commitment to welcome migrants and from high financial capacities at its disposal. In another case, discourses revolved around a city's financially constraints, which were equalized by compensatory civil society networks. In other cities, progress was associated with spontaneous local happenings or individual innovative leadership. These street-level patterns create a degree of locality within the global migration discourse, since they emerge from the interplay of financial, economic, and demographic features; historical concepts; or local events. We therefore contend that urban planning initiatives would profit from considering place-specific institutions that influence integration stakeholders, which are regime-makers and foster institutional, migration-led changes.
\end{abstract}

\section{Keywords}

city-specificity; institutions; integration strategies; migration; spatial analysis; urban context; urban migration regimes

\section{Issue}

This article is part of the issue "Migration-Led Institutional Change in Urban Development and Planning" edited by Robert Barbarino (TU Dortmund University, Germany), Charlotte Räuchle (Free University Berlin, Germany) and Wolfgang Scholz (TU Dortmund University, Germany).

(C) 2021 by the authors; licensee Cogitatio (Lisbon, Portugal). This article is licensed under a Creative Commons Attribution 4.0 International License (CC BY).

\section{Introduction}

When a growing number of refugees, mainly from Syria, left their country to enter the EU via Central European countries in 2015, but were stopped at the Hungarian border, German Chancellor Angela Merkel famously announced: "We can do it." In the following year, the number of asylum applications reached more than 745,000 in Germany and, for the first time, exceeded the historical peak from 1993 (about 440,000 applications in the course of the Yugoslav wars; German Federal Office for Migration and Refugees, 2020). Even though the numbers have steadily decreased since then, dropping to about 122,000 applications in 2020 (German Federal Office for Migration and Refugees, 2020), German society, as well as the European Community as a whole, has become increasingly polarized between those representatives accepting and welcoming new migrants into 
their communities, and others rejecting them, supposedly due to their overburdened local integration capacities. In addition, the emergence of some radical, or even aggressive populist resentment has increasingly been undermining societal cohesion.

Despite these recent political turbulences, migration is not a new topic for German society. According to German population statistics, migrants are defined as 'persons with a migrant background' (Federal Statistical Office, 2017), meaning that the individual concerned, or at least one parent, did not receive German citizenship by birth. This definition varies from other concepts used at the international level. The United Nations (2019, p. 3) defines international migrants as persons "who are either living in a country other than their country of birth or in a country other than their country of citizenship." However, we use the German concept in this article since it subsumes the diverse immigration groups in Germany's recent immigration history. This includes immigration of 'guest workers' from the 1960s; ethnic German repatriates from the former Soviet Union, Poland, and Romania; the refugees with peaks in the 1990s and around 2015; or immigrants in the context of EU free movement. Parallel to a decline of immigration at the turn of the millennium, a critical debate evokes questioning whether integration is still an adequate terminus to be used (West, 2013), not least since many immigration groups have been living in Germany for almost half a century. As a consequence, scholars within the academic discourse have gone a step further and analyzed Germany according to its 'postmigrant' identity building (e.g., Foroutan et al., 2014). Nonetheless, with recent immigration peaking in 2015, these discussions devolved again into rhetoric on immigration that can roughly be put between exclusion and welcoming culture (cf. West, 2013). In the meantime, the country has become one of the top global destinations of immigrants-comparable with Saudi Arabia-and, in 2019, hosts around 13 million migrants and thus stands at second place following the U.S. (51 million; United Nations, 2019). While already back in the 1970 s there was a debate on whether Germany should in fact be termed a country of immigration due to its high numbers of international migrants (Filsinger, 2009), Germany is now once again challenged to strengthen social cohesion in order to stop an increasing polarization of German society.

This future of the German immigration society depends to a great extent on how successful integration will be at the local level. This is particularly relevant in urban areas, since large gateway cities, but also suburbs or some smaller-sized towns, have proven attractive for migrants (Çağlar, 2014, p. 8), causing them to function as integration hubs in global society. It is here, in these cities, where it will be determined if "we can do it" or not. As a consequence, integration strategies have become central tasks in modern urban planning. The efforts to provide successful integration strategies, however, vary greatly between cities. With a comparative case study in four mid-sized German cities, the article aims to show how institutional and structural conditions influence local discourses of stakeholders in urban migration regimes. It uses key statistical data from the cities and discourses from semi-structured interviews with urban integration stakeholders, i.e., individuals working for local authorities, welfare associations, and non-governmental organizations. These urban authorities and civil society representatives who are providing integration services, measures, or programs are core players within the urban migration regimes, which we define as an ensemble of local discourses, institutions, networks, and power relations related to the processes of arranging and negotiating the challenge of migration and integration (cf. Pott, 2018, p. 121).

The article begins by introducing the theoretical framing and method. This is followed by a detailed analysis of the discourses with integration practitioners in the four cities, which will show that urban agents are strongly shaped by local institutions, and, at the same time, these stakeholders as regime-makers themselves form placespecific institutions. We then close with a synopsis on our findings about the meaning of locality and draw conclusions for urban planning initiatives and the global migration discourse.

\section{Contextualizing Urban Migration Regimes in Their Local Institutional Context}

Despite a heated public debate about local policies in dealing with refugees' immigration peaking in 2015, Schammann (2015, p. 162) misses an equally intensified research debate on local immigration policies in the German context, especially in politics, which is still mainly focused on national and European political development. The few existing studies, moreover, are primarily focused on metropolises (e.g., Pütz \& Rodatz, 2013; Wiest, 2020), despite the fact that also smaller and medium-sized cities are becoming increasingly relevant as places where migrants settle (Çağlar, 2014, p. 8). By analyzing discourses and inherent institutions in four medium-sized cities in Germany, this article aims at responding to the lack of locality studies in the German context. It is contextualized in two major theoretical avenues.

First, we draw from existing locality approaches that were mainly conducted in the U.S.-American context and investigated the role of different "historical, institutional and discursive trajectories" (Çağlar, 2014, p. 17) for the existence of local patterns of urban immigration and integration policies. To give some examples, Bauder (2016) discussed how local policies and practices of 'sanctuary cities' differ in international comparisons throughout socio-demographic, historical, and political contexts within cities. Similarly, in the U.S.-American context, Walker and Leitner (2011) found specific reasons (e.g., the geographical location of cities, the share of foreign-born population) for the fact that local policies 
are directed "either to promote immigrant integration or to exclude (undocumented) immigrants from settling" (Walker \& Leitner, 2011, p. 157). Glick Schiller (2013, p. 888) detected varying "narratives of culture and creativity," such as the promotion of multiculturalism as a tourist attraction in Paris, and an open image for global talent-seeking in Dallas. In the German context, for instance, Wiest (2020) has illustrated the influence of historical conceptions and socioeconomic conditions on local attitudes towards migrants in districts of Munich and Leipzig, ranging from "unexcited and routinized coexistence" in more cosmopolitan, economically wellpositioned urban regions of Munich, to more skepticism in the East German city related to "realities and debates of racism and growing xenophobia" (Wiest, 2020, p. 123). A further example is provided by Schammann (2015, pp. 177-178), who illustrated that the Asylum Seekers' Benefit Act or Asylbewerberleistungsgesetz is implemented in German municipalities differently, depending, roughly put, on welfare-orientated, liberal or regulatory, restrictive policies. Outside the rather narrow field of migration studies, these approaches correspond to the broader idea of an 'inherent logic of cities,' a term coined by Berking and Löw (2005). This logic is assumed to be the result of historical conceptions and a comparative understanding of a particular city against other cities. For instance, Gehring and Großmann (2014, p. 111) found that, due to the affirmation of certain self-images or even symbolization, the experts they interviewed ascribed different connotations to problems depending on which city they belonged to.

To adequately reflect the evolution of these kinds of local patterns and variations, as a second theoretical avenue, we draw from institutional theory, thus paying attention to the dynamic and complementary character of underlying institutions and structures. Even if a common definition of institutions is still missing (cf. Glückler, Suddaby, \& Lenz, 2018, p. 3), the widely-established differentiation by Scott (2001) into regulative (e.g., legal or economic factors), normative (e.g., values, traditions), and cognitive institutions (e.g., common believes) can be used as orientation. Glückler et al. (2018, p. 2) recognize a growing interest in the "spatial dimension of institutional life." These authors (Glückler et al., 2018) argue that-next to an 'institutional turn' in geography-a 'spatial turn' in institutional theory that culminates in questions like "what it is that makes it easier to unlock the potential of one region than that of another" can also be observed (Glückler et al., 2018, p. 2). By applying this approach to migration studies in our empirical analysis in order to understand institutional and structural conditions for local variations, we also address the shortage of enhanced theoretical analyses on the production of (urban) space in the context of migration regimes (Pott, 2018). The study responds to an increased need for qualitative approaches in migration studies so that one can capture the complexity of factors and the role of individual and social movements responsible for different urban immigration policies as proclaimed by Walker and Leitner (2011, p. 174). Considering that these movements "do not exist in a vacuum," but rather evolve within a specific milieu out of the specific "local social, demographic, and geographic context of these policy responses" (Walker \& Leitner, 2011, p. 174), our study seeks to explain the reasons why local variations exist and, thus, why something happens in one city but not in another. The substance of a locality becomes relevant as an expression of social relations and movements and, thus, in line with Dell'Agnese (2013), the geographical boundary of the city is referred to as a level of abstraction in order to conceptualize space.

\section{Method: Localizing Urban Migration Regimes in Four German Cities}

In Germany, the four states of Bavaria, BadenWürttemberg, Hesse, and North Rhine-Westphalia have the highest shares of migrants outside the city-states or Stadtstaaten (see Figure 1). In order to spread the case studies across the country, one city was selected in each of them. Thus, the focus is given to cities in the Western part of Germany, with the awareness that cities in the Eastern part reveal specific, more skepticism patterns in dealing with migration as highlighted in other studies (e.g., Wiest, 2020). We specifically focus on small and medium-sized cities with a population between 50,000 and 150,000 (see also section above). For the selection process, the economic and sociodemographic background of 89 cities (selection criterion: proportion of migrants above national average, i.e., > 19\%; Federal Statistical Office, 2017) within these four federal states were evaluated in terms of the following three aspects: share of migrants (indicator: share of migrants), financial and economic capacities (indicators: core fiscal debt per capita and unemployment rate), and knowledge assets (indicators: highly qualified individuals at place of residence and at place of work).

As a result, the following four cities were chosen (see Figure 1): Arnsberg, a rapidly aging city, has the smallest share of migrants of the four cities (20.2\%), moderate financial and economic capacity, and a fairly small proportion of highly qualified employees (8.7\%); Erlangen, a center of the 'knowledge society' (traditional university town, numerous high-tech industries), has a moderate share of migrants $(28.7 \%)$, a strong financial capacity, and a significant share of highly qualified employees (31.2\%); the third city, Heilbronn, is a stable, dominant economic center in its region and has a high proportion of migrants (43.7\%) and a strong financial capacity, but only a moderate number of highly qualified employees (11.9\%); and Offenbach, just east of Frankfurt, a traditional industrial location currently undergoing structural transformation. The city has the highest share of migrants in Germany (49.7\%) and the weakest financial capacity (and the highest unemployment rate) of the four cities. Furthermore, it has a relatively large segment 

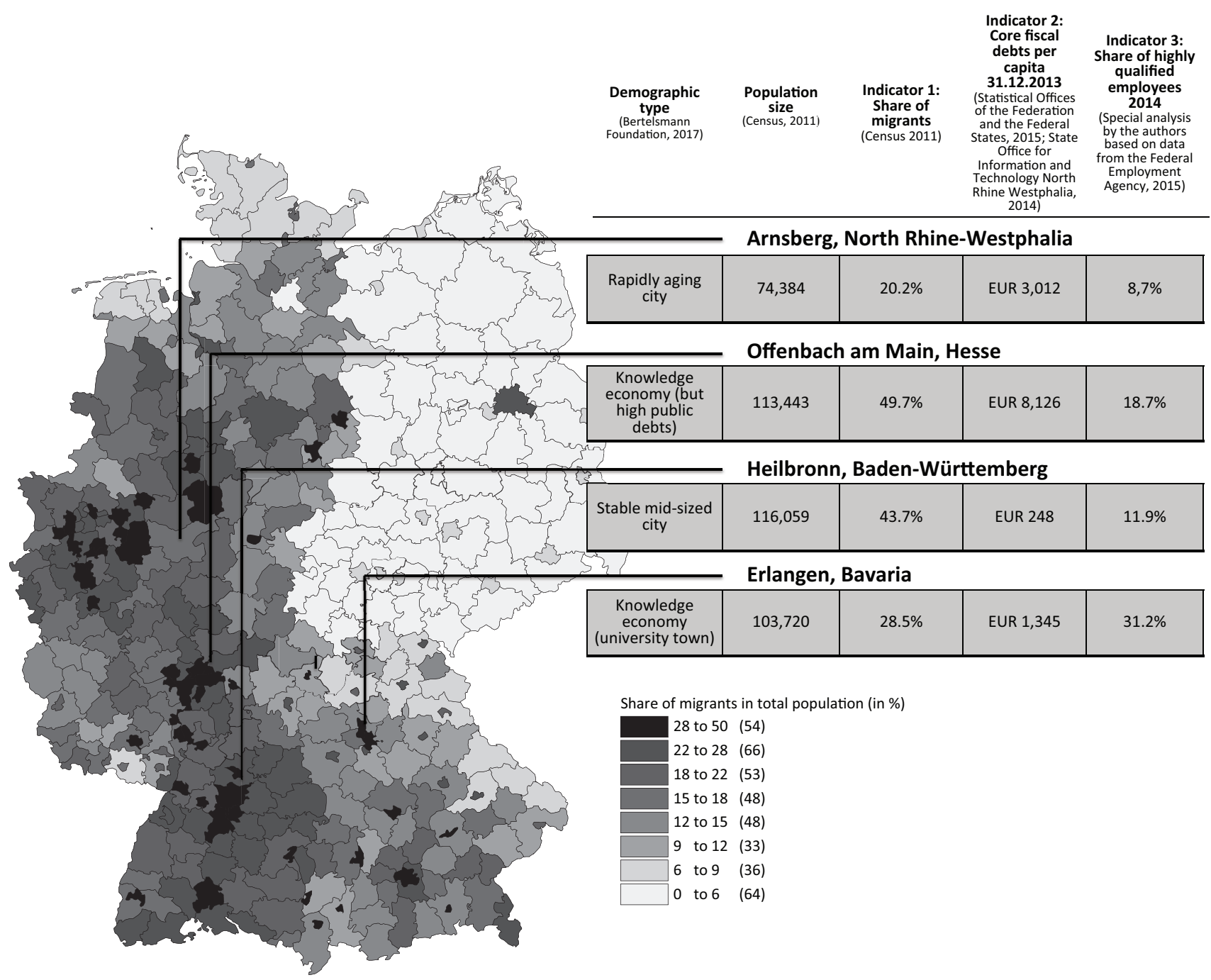

Share of migrants in total population (in \%)

Figure 1. City characteristics of the four urban case studies in Germany.

of highly qualified employees $(18.7 \%)$ due to its vicinity to the global metropolitan region of Frankfurt.

All four cities have high shares of migrants from earlier periods of immigration (e.g., generation of 'guest workers' or ethnic German repatriates), but also show some more recent particularities (e.g., a particularly high level of immigration of EU citizens to Offenbach and the increased reception of refugees in Erlangen).

A total of 35 semi-structured interviews were conducted with integration practitioners in these four cities. Interviewees from the following groups-in equal proportions-were included: 1) charitable associations, representatives from councils of foreigners, and social enterprises, 2) welfare associations, and 3) local authorities. These experts are active in the field of integration for the cities on a salaried or voluntary basis and provide projects, programs, or measures that are directed toward improving integration in different areas of life. This includes immigration counseling, mentoring projects, vocational orientation, talent seeking programs, sport programs, or intercultural projects such as intercultural gardening or intercultural theatres. All interviews asked about the aim of the experts' own services, a general assessment of which factors enable or hinder practitioners from acting innovatively, and local attitudes towards migrants, as well as future challenges for the city and the experts themselves. The interviews were transcribed and then analyzed with the help of MAXQDA using a deductive/inductive method of categorization (Kuckarz, 2014). The deductive element was used since the interview guide was originally directed to prove the practical relevance of an existing indicator set on social innovativeness (results published already in Bund, 2015; Bund, Gerhard, Hoelscher, \& Mildenberger, 2015). However, the analysis additionally included an inductive part because we gave the interviewees the most possible freedom to talk about those themes that bother the experts most. This inductive part has revealed three main themes and builds the starting point for the following analysis (see Figure 2): main motivation of the experts as a response to the most pressing challenges in the cities, the experts' specific assessment of the local government strategy, and their collaboration with other key stakeholders in terms of power relations. As a second 


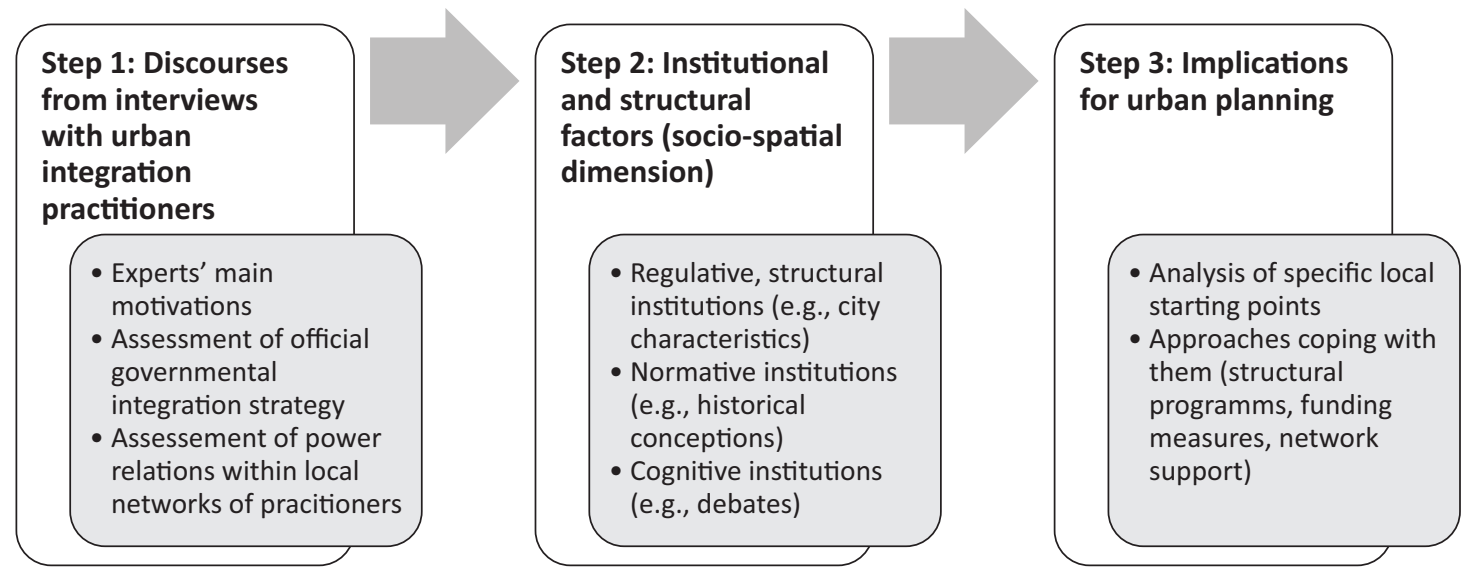

Figure 2. Study design.

step, when presenting these discourses, we pay particular attention to the institutional and structural elements underlying them. From here, as a third step, we derive some approaches for urban planning in the conclusion.

The research design has also some major limitations. The selection process for these urban case studies is only exemplary but, nonetheless, we use these structurally diverse cities as prototypes that are studied, not for their own sake, but as "specific exemplars of some more general phenomenon whose investigation as part of the complexities of the particularity of places enables a closer analysis of its real workings" (Massey, 1993, p. 148). Furthermore, using the perceptions and discourses of integration practitioners of course implies the risk of respondent bias in the experts' reporting of institutional capacities or characteristics of their cities. We tried to mitigate this by representing the whole network of integration practitioners from all sectors. The experiences from the interviews let us assume that experts might be partially concealing problematic concerns, especially in contributions by local authority experts, but they also include unexpected critical voices by local authorities as will be shown in the analysis.

\section{Analyzing City-Specific Discourses in Urban Migration Regimes}

In this section, we analyze in more detail the specific discourses in each city. The three main themes will be analyzed for every city (Step 1) by using exemplary quotes from the interviewees. Which institutional and structural conditions are relevant for the development of cityspecific discourses will be discussed and summarized for each theme (Step 2). A synopsis of these two steps is given in Figure 3, while the implications for urban planning are discussed in chapter 5 (Step 3). As will be shown, there is a complex interplay of factors that determine the evolution of these discursive streamlines. As our qualitative analysis has established, the key characteristics of cities is one of several factors that is of relevance here.
To protect the anonymity of the interviewees, only rough attributes are given: the first part refers to the organization the expert belongs to ('ngo' for migrant associations and social enterprises, 'welfare' for welfare organizations, 'authorities' for local authorities). The second part refers to the city the expert belongs to (ARN for Arnsberg, ERL for Erlangen, HEI for Heilbronn, and OFF for Offenbach am Main). Finally, the interviewees were numbered consecutively in each city.

\subsection{Main Motivations of Urban Stakeholders}

The first theme addresses what the urban stakeholders view as the cities' biggest challenges they try to respond to with their work. In Offenbach, a city with a particularly high share of migrants, the biggest challenge in the view of many experts is the particularly high pressure to act. All representatives from the welfare associations complain about overburdening: "With the 40 hours I work here every week, I cannot accomplish everything" (welfareOFF3). Another example is the following statement: "Think about it: we have $50 \%$ of people with migration background and four suppliers for immigration counseling....I have had 662 cases in the last year.....And that's not counting the Bulgarians" (welfareOFF5). Some stakeholders believe that the city's economic difficulties have been exacerbated by immigration:

Those [foreign guest workers] who-after the industrial sector had disappeared-stood on the street....That is what the city of Offenbach is still taking its time in coping with....Until the 1970s we had immigration for the purpose of employment...now it again shifts towards immigration in the context of free movement of people coming from Eastern Europe. (authoritiesOFF1)

This challenges the urban strategy: "A city that...is itself poor...then if other social groups come they are made into scapegoats" (welfareOFF5). Several experts see a kind of polarization in the city. A critical assessment of 


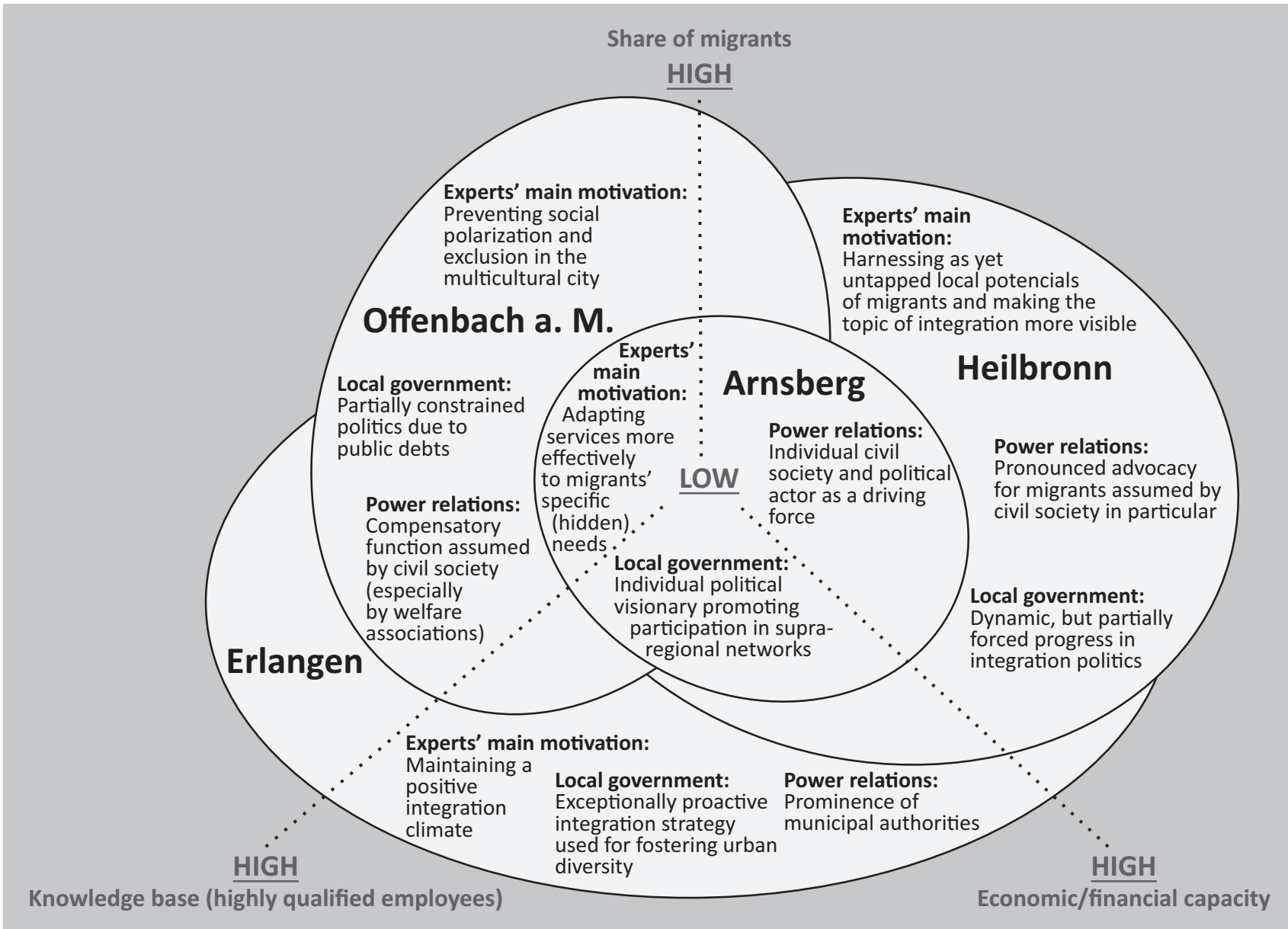

Figure 3. Synopsis of city-specific discourses and their relation to city characteristics. Note: For detailed information on structural data see Figure 1.

the multicultural flair, however, is the exception: "You only have to go in the city center of Offenbach. There is nothing German anymore. Even the C\&A is a Turkish clothing store" (ngoOFF6). However, a recurring motivation among almost all experts is to create initiatives for peaceful coexistence in the multicultural city-an exemplarily statement is the following one: "When you walk onto the market square, you hear thousands of languages you don't understand. And I am delighted. I say we have the whole world here at home. Why do we only see problems?" (welfareOFF4).

Heilbronn, a city with also a particularly high share of migrants, was an attractive destination for 'guest workers' and ethnic German repatriates. In Heilbronn, however, preventing polarization was not the major theme of the interviews: "Considering that in the inner city $46 \%$ of the people have migration background, one can state that it is quite peaceful here" (welfareHEI3). The most frequently recurring topic voiced by the integration stakeholders was their strong motivation to harness the untapped potential of migrants. Several stakeholders stress the idea that the city would certainly benefit from greater efforts to integrate migrants into the education and labor system and to enhance political participation: "If the city acts right now regarding these foreign teenagers, it can only profit from it" (ngoHEl2a). This main objective is addressed by several initiatives. For instance, this includes an association committed to new talent seeking in the Turkish communities or an intercultural theater that, with its theater productions and subsequent discussions with the audience, aim at reflecting local realities in immigration societies (e.g., conflicts in Turkish families when young people turn away from religion). The experts, especially civil society actors, place greater emphasis on this objective of unfolding potentials and making the topic of integration more visible because some of them still observe distanced attitudes toward migrants, as illustrated by the following quote: "It's not necessarily xenophobic, but people in Heilbronn are also sometimes distant because they don't know how to deal with strangers" (ngoHEI6).

The lower share of migrants in Arnsberg, in turn, is also reflected in the interviews. Some experts even report about a partial lack of demand for the services:

It's just that I always need a certain number of participants-about 10, 12 participants-and I can't get so many people together.... However, many cultural groups are living here that are just wellintegrated too; they live with us and among us 
and they don't want to hear anything from us. (welfareARN4)

However, this increases their motivation to adapt services more effectively to migrants' specific needs: "One has to join forces and begin by determining the needs.... One really has to go out there and ask which projects we can establish" (welfareARN3). The pressure to act is not as great as it was during earlier periods of immigration: "For instance, in the course of the Bosnian war...there was an integration climate that could have taken a negative turn" (ngoARN5). The recent situation thus gives them the opportunity to address the more hidden needs that indeed exist, such as in cases of social isolation of women or intercultural conflicts as cited by an NGO representative: "For example, we had a Kurd [in the project], and then the Turkish participants didn't want to participate in the project anymore. That is interesting...the problems are being brought here by migrants" (ngoARN7).

Finally, in Erlangen, many experts refer to the immigration history of the city starting from the Huguenots to the later immigration of Siemens employees or of refugees: "Well, the city is used to it already, but just with all the Siemens employees, who come from all over the world...every now and then there is one weirdo who sees things differently, but those are exceptions here in Erlangen" (ngoERL2). However, in Erlangen, a controversial debate on refugees' housing arrangements has begun, thus challenging the-in the view of all expertsgenerally largely open-minded attitude towards migrant integration that many stakeholders aim to maintain. Statements like the following ones are found in almost all interviews in the city:

There are sometimes-how shall I put it-situations in which you realize: Okay, it's not like that yet, at least not among the whole population. What has been going on with the refugees just now...[namely] that many neighbors [i.e., citizens who are living in the vicinity of refugees' accommodations] were scared. (welfareERL3)

Some experts were surprised to see this kind of critical debate arising: "And then we thought: Whoa there! From Erlangen? With its 'tradition of openness'?" (ngoERL7)the city's official slogan.

To sum up (see also Figure 3 ), the local situations and dominant themes that trouble the experts differ strongly in the four cities. In the two cities with a particularly high share of migrants, the experts are mostly challenged by a huge pressure to act, especially in the field of immigration counseling, where there is a requirement to prevent polarization and a desire to harness the yet untapped potentials of migrants. In turn, a lower share of migrants gives integration practitioners the opportunity to uncover hidden needs or to maintain an overall positive integration climate. This is backed up by other studies that show that the share of migrants (e.g., Wells, 2004) and especially the growth of this share in cities (Walker \& Leitner, 2011) play a major role in accounting for differences in local integration policies. In this regard, it is decisive if the individual pressure can be met by a local government or if cities become overstrained. These aspects will be addressed in the next section.

\subsection{Assessment of Local Government Integration Strategies}

Progress and innovativeness of integration highly depend on whether the local authority is able and willing to see integration as a cross-sectional and high-priority process (e.g., Gruber, 2010). Apart from a rough differentiation into service-oriented, inclusive, and regulatory politics (cf. Marrow, 2009), the motives that underlie specific city marketing differ in cities and range from traditional "belief systems" (Walker \& Leitner, 2011, p. 165) to multicultural city strategies that are directed toward a "fabrication of exotica" (Shaw, Bagwell, \& Karmowska, 2004, p. 1984). In our analysis, with the help of the experts' assessment on how they view the local governmental strategy in their city, we present examples to reflect these differences in local policy styles.

In Erlangen, almost all experts acknowledge that the city has an exceptionally proactive integration strategy: "There is a sense of cosmopolitanism-which is the city's slogan: a tradition of openness. You can feel that" (welfareERL3). To illustrate the historically-rooted meaning of migration, the local authorities even started a project on the city's immigration history in collaboration with the town museum. Similarly, Walker (2014, p. 524) discussed the historical dimension of such inclusive integration strategies. The inclusive policies in her study in suburbs of Evanston and Takoma Park-in a way similar to Erlangen-were grounded in a "tradition of welcoming immigrants and promoting social justice" that evolved as part of a longstanding experience with immigrants at these places, "which may in part explain their more tolerant positions" (Walker, 2014, p. 524). An important driver for introducing a culture of welcoming in Erlangen was a problematic concern in 2011 about one employee of the city's immigration authority who was accused of treating refugees in an inhuman way. This conflict was broadly discussed in local media as 'Sheriff merciless': "This landed as a kind of bombshell in the town hall" (ngoERL5). A welcoming principle was pursued from this time forward by the coordinating office for integration. This office was introduced in 2008 and local authorities attach great importance to the sustainability aspects of their projects: "When we start a project, I always try to support it with communal budgets in order to increase its sustainability" (authoritiesERL1). For instance, two large-scale projects that were initially financed by external funds have been continued by the city itself. This includes a project on educational sponsorship or a club as meeting point for intercultural exchange. 
In other cities, they claim that projects depend much more on external funding. Then it is important to quickly respond to such external calls, find partners, and provide a formal statement by the local authority to confirm that a specific local need really exists. Thus, having a well-equipped integration staff, as is the case in Erlangen, allows for more supportive structures and thus affords the luxury of fostering innovative projects with the help of both internal and external funding.

Despite a similarly high proportion of migrants and an equally reliable financial situation like Erlangen, it can be assumed from the interviews in our second city, Heilbronn, that the progress made in integration strategies was partially forced by public pressure resulting from newly released population statistics that were published as part of the city's second integration report (City of Heilbronn, 2014). The report actually revealed an unexpectedly high share of migrants in the city: "And there I felt a great deal of insecurity and that many people saw the numbers for the first time, and they were completely stunned: What, so many?" (authoritiesHEI1). Prompted by the publication, dynamic progress was initiated and many interviewees in Heilbronn are grateful to the integration commissioner, whose position was initiated in 2008 and later on assigned directly to the mayor's office (City of Heilbronn, 2014, p. 25): "Since the position of integration commissioner was created, the city has already set an example; they see something needs to be done. There had been initiatives before of course, but not pooled like that" (welfareHEl3). Firstly, this proves the capacity of a financially well-positioned city to quickly build well-structured networks, and, secondly, illustrates that spontaneous developments can change policy styles within a short time (see Daamen \& Doomernik, 2014, who reported the spontaneous arising of regulatory policies in the course of a violent crime caused by an unauthorized migrant).

In Offenbach, a proactive government strategy is hampered by scarce financial resources. Even if several stakeholders argue that the city started their engagement for integration relatively early-for instance an integration commissioner was installed in 1998-they also indicate a missing overview of the variety of existing integration measures and insufficient coordinative power of the local authority: "We tried...to provide transparency. Which measures? That [namely providing an overview of existing integration measures] is not possible...we don't have personal resources to do so...so many measures...but principally the same approach" (authoritiesOFF8). This is related to the limited financial capacity of the city: "The most important thing is definitely to overcome the debts" (authoritiesOFF1). A representative of the welfare association put it more dramatically: "I think Offenbach is the second most indebted city in Germany; nothing can be done here anymore....I guess you could actually remove politics here" (ngoOFF6). The federal state of Hesse, for example, provided funding for a project, which strengthens the role of migrant associations and thus helped the local authority to at least partly compensate for its financial difficulties. Some experts also explain that the city, in the course of increased immigration of Bulgarians and Romanians, has been focusing on security and regulatory issues. This is an issue raised by several interviewees: "Well, they don't want to have poverty immigration anymore....The city of Offenbach has undertaken regulatory measures consistently and on a massive scale...so integration policies are subordinate" (authoritiesOFF1). This also affects the society as a whole in the view of some experts: "That means, regulatory measures, overstaffed houses, deporting illegal people or not allowing them to come herethat influences the society very much, if this is in the media" (ngoOFFO5).

Arnsberg, finally, has a relatively low proportion of highly qualified individuals and is also the smallest and most peripheral of the four cities while enjoying considerable recognition in superregional networks (for instance, as a member of the European network CLIP-Cities for Local Integration Policies). Many interviewees associated the recognition it enjoys with the strong support for political visionaries: "We have a very innovative mayor.... He's a driving force...a pioneer" (authoritiesARN1). This strong political visionary shows that individual dynamics play a seminal role for local regimes-independent from other structural constellations. In Arnsberg, the restructuring of the immigration authority toward an office for immigration in 2000 started relatively early compared to other cities and has installed its own staff unit: "Begging to department heads...that will not work; rather it has to be a mandate from the highest administrative level, then it will be taken seriously" (authoritiesARN1).

We conclude from this section that integration stakeholders are confronted with different local policy styles ranging from very proactive strategy making in the field of integration to partially insufficient political structures. With regard to the frameworks relevant for the evolvement of these local patterns, our case studies have shown that structural conditions such as the financial situation of a city (see Figure 3 ) impact not only on local authorities, but also on the whole network of integration practitioners. It has furthermore illustrated that progress in governmental integration strategies can also be fostered by historical dimensions, but also by public pressure due to certain events, advocacy assumed by civil society, or individual innovation leadership.

\subsection{Assessment of Power Relations within the Local Network of Integration Practitioners}

In urban research, the negotiation of power is also related to processes and arrangements between urban government and non-governmental actors (e.g., Hendriks, 2014). Some authors even refer to an individual "geography of nonprofits" at the local level (DeFilippis \& Faust, 2014, p. 1198) and describe the 
dependency of the civil society's scope on specific structural conditions (e.g., Lake \& Newman, 2002). In our selected cities, power relations become evident in terms of a varying "immigrant advocacy assemblage" (Leitner \& Strunk, 2014, p. 951) that ranges from the dominance of government actors to a variety of non-governmental stakeholder groups.

The proactive governmental strategy in Erlangen, having the highest share of highly-qualified employees in our study, goes hand in hand with a high municipal dominance in integration issues: "All the activities or actions related to the topic of integration...are usually controlled and organized by the city of Erlangen" (authoritiesERL8). An example illustrating this coordinative engagement of the local authority is the socalled integration conference taking place every year that is used for presenting integration activities of the city to citizens and interested audiences. Van Winden, van den Berg, and Pol (2007, p. 529) described structural characteristics of 'knowledge cities' like Erlangen and one criterion is their high degree of urban diversity including cultural diversity. In Erlangen, this endeavor to foster urban diversity is reflected by the local authority's strong commitment to ensure sustainable, professional integration services. As shown by several studies, there is a correlation between a large number of citizens with advanced university degrees or absence of economic insecurity and a pro-immigrant perception (e.g., Daamen \& Doomernik, 2014; Gerhard, Hoelscher, \& Wilson, 2017; Walker \& Leitner, 2011). One expert expresses this as follows: "Erlangen is a rich city. Siemens, the university, everything is here. If you do not have to fight for your own livelihood, it is quite simply much easier to be generous and sympathetic" (ngoERL5). However, a strong municipal dominance may also carry a risk of turning into rigidity. For example, when too much focus is put on justifications such as survey data or evaluations used by the cities to demonstrate that a certain project is successful in addressing a specific local need. The ability to respond quickly "is one aspect that is missing in the city in the context of innovativeness. Thus, they [the local authorities] always need a justification for everything" (ngoERL2).

Power relations in Heilbronn are very different from Erlangen. The network of urban stakeholders in the view of the experts is generally very cooperative, but we found a particularly pronounced advocacy for migrants assumed by civil society in Heilbronn, which overtakes-close to what Leitner and Strunk (2014, p. 960) call-“struggles...for more welcoming policies": "Because there were simply enough young migrants who had the knowledge and the skills, and we said: The time has come now. Now we have to act too. And we have to show ourselves" (ngoHEI6). In Heilbronn, the interviews give the appearance that there is still a need to build trust on the civil-society level and to gain greater recognition of the topic of integration in the city. Some urban stakeholders are thus still heavily engaged in assuming advocacy for migrants, which, in their view, the local author- ity does not sufficiently care for in the past. This is similar to what Bauder $(2016$, pp. 5,8$)$ found in the United Kingdom in terms of "grassroots practices of solidarity" pursuing the aim "to create unity among activists, urban political and civic actors, as well as illegalized migrants and refugees" (Bauder, 2016, p. 8) as a sign of neoliberal politics. Looking back at how their initiatives began, many of the civil society actors in Heilbronn broach the issue of building trust in civil society within the urban context: "So it's a lot of personal spadework, persuading and also cultivating contacts" (ngoHEl6). This advocacy and their persuasive endeavors, along with a kind of defiance on the part of some civil society actors, reveal a dynamic moment of shifting power in Heilbronn.

In Offenbach, too, civil society is an important player within the local network. However, compared to Heilbronn, where the interviews give the appearance that there is still a need to build trust with civil society, here especially welfare associations have become highly respected players: "Yes, it works very well in Offenbach. And if one [representative of welfare associations] says something in working groups, it works" (welfareOFF4). This expert makes the point that, for example, the police or regulatory official agents do not dare to talk in a negative manner about specific immigration groups in their presence. Networks are, in the view of all experts, of great significance against the backdrop of the financial constraints on local authorities: "If one has almost no money, it does not work at all without networks" (ngoOFF6). Thus, agreeing with the view of several experts in Offenbach, a robust and compensatory civil society network has developed as a counterpart to the local authority's limited capacity: "We strongly cultivate this network in Offenbach" (welfareOFF3). Especially the experts from welfare associations report unanimously that collaboration is characterized by high levels of trust and an effective, flexible use of skills and competences among the individual agents of the local network. One example clarifies it: "I like to give some people away, take others on, and so on; everyone [the colleagues] knows their preferences, special qualifications, who one can cope with best, what one doesn't like; we know all of that because we've been working with that colleague for years" (welfareOFF5). This kind of flexibility, however, is also necessary as shown by the following quote: "The suppliers of immigration counseling have always been treated as stepchildren to a certain degree....We/the suppliers comprehensively support each other" (welfareOFF3).

Finally, in Arnsberg, in addition to the role of political visionaries, all experts expressed their gratitude to one particular charitable association that was established in 1969 , and still plays an outstanding role in the overall integration network today, and in close cooperation with local authorities is caring for the language development: "The biggest accomplishment was that she [the founder of the association] drew political and public attention to the need for action; that people [the migrants] couldn't 
simply be left alone" (ngoARN5). This association organizes the yearly event 'DIES Internationales' as a platform to present organizations in the field of integration, and includes shows and culinary specialties, as well. This is a prominent event, even beyond the city borders and appreciated by all interviewees. These individual initiatives are mainly responsible for the city's positive reputation throughout Germany with regard to its best practice models for improved integration.

Power relations in cities thus vary strongly between municipal dominance and compensatory civil society networks. Shortcomings such as financial constraints of local authorities can be partially compensated by a strong civil society. Furthermore, backed up by existing studies, a high number of highly-qualified persons in the population (see Figure 3) might also foster an increased municipal power fostering knowledge-induced growth and urban diversity by pursing a proactive strategy in dealing with migration and integration. In cases where a clear assignment of power was not possible, our analysis confirms the role of 'opinion leaders' that, as individuals, are strongly involved in capacity-building for institutional transformations (see also Mutch, 2007).

\section{Conclusion}

Our analysis directs attention to the complex interplay of regulative, structural institutions (e.g., financial, economic, demographic features), normative institutions (e.g., historical conceptions), as well as cognitive institutions (e.g., local debates) that, in a complementary way, produce a specific urban environment in which local variances -in this article illustrated by city-specific discourses-evolve. In summary, the discourses revealed some major tendencies. One, for instance, is that especially stakeholders in the field of immigration counseling are confronted with signs of overstraining in those cities with high shares of people with migration background or strong recent immigration flows. Structural conditions such as the financial situation of a city impact not only on staff in local authorities themselves, but also on the whole network. This is because strong engagement by municipal integration actors helps to provide a well-structured, transparent landscape of integration services, preventing double work and supporting application processes toward third party funding. Moreover, in the case of local authorities lacking capacities, a mechanism allowing for compensatory networks in civil society is of fundamental significance. Historical dimensions, including the maturity and power of networks or individual experiences with earlier immigration, are equally important conditions shaping variations in the discourse of the urban agents. Finally, a proactive urban migration regime can also be fundamentally fostered by individual innovation leadership or the potential of spontaneous events for turning around local politics. Migration studies are thus challenged to precisely analyze the complex dynamics of the production of (urban) space (Pott,
2018, p. 113). We focused on the integration practitioners as key players within these regimes. Without having longitudinal evidence, the examples from our analysis selectively show that these practitioners commit to a tradition of openness, they arise awareness to the realities of immigration societies, or they join forces and compensate the missing capacities of local authorities. With their 'voices' negotiated within and along local and over-regional networks in "spaces of circulation" (Jonas \& Ward, 2018), these urban agents can be regarded as 'regime-makers' and they have major responsibilities in the negotiation of processes on migration and integration at the local scale.

Shedding light on this rhetoric on the origins of discourses of successful or failed integration policies by cities will help to moderate today's controversial and often very emotionally-charged debate on migration. Understanding these origins is an important feature for bottom-up policies and urban planning (Step 3 in Figure 2) because it takes into account which individual opportunities and challenges exist within urban frameworks (for the role of knowledge institutions in these urban planning processes see van Winden, 2010). This applies, first, to analyzing structural starting points and institutional factors such as specific historical conceptions or power constellations within cities. Second, based on these observations, planning and policy makers can address these starting points with the help of structural programs and funding instruments that foster self-help, and are of particular relevance to those cities that are affected by structural change and limited public financial capacity. The results from our interviews underline that there is also a necessity for thinking about alternative funding instruments that also enable a donor to access representatives of cities that do not have the capacities for undertaking a professional application process. A further instrument refers to the promotion of (existing) networks at different levels that have to be used for knowledge exchange and particularly to pass on good-practices that might derive especially from cities that have the specific possibility to pilot innovative projects and sustain effective (elements of) projects.

Finally, 'regime-making' as a process constantly in motion does not end at the local level; rather, these regimes are embedded into national and global scales that are mutually interdependent. We began this article with a quote by German Chancellor Merkel in 2015 which could be paraphrased as "Yes, we are responsible and willing to practice integration." As this article has shown, this general call to action needs a profound, localized response in terms of place-specific integration strategies that-in an admittedly rather complex way-adhere to local institutional frameworks with their specific histories, limits, and opportunities. Then, local integration can be improved by identifying strategic failures and challenges. Integration strategies thus have to be viewed as a result of individual capacities among local governments and civil society actors. The place-specific institutions on 
which these capacities rely provide the important substance of locality necessary for the global migration and integration discourse.

\section{Acknowledgments}

We thank the two anonymous reviewers for their thoughtful comments on this article. The empirical part of this work was funded by the Research Council of the University of Heidelberg, Field of Focus 4 'Self-Regulation and Regulation: Individuals and Organizations.'

\section{Conflict of Interests}

The authors declare no conflict of interests.

\section{References}

Bauder, H. (2016). Sanctuary cities: Policies and practices in international perspective. International Migration, 55(2), 174-187.

Berking, H., \& Löw, M. (2005). Wenn New York nicht Wanne-Eickel ist...[If New York isn't Wanne-Eickel...]. In H. Berking \& M. Löw (Eds.), Die Wirklichkeit der Städte [The reality of cities] (Soziale Welt [Social world] Special Vol. 16; pp. 9-22). Baden-Baden: Nomos.

Bertelsmann Foundation. (2017). Demografietypen [Demographic types]. Wegweiser Kommune. Retrieved from http://www.wegweiser-kommune.de/ demographietypen

Bund, E. (2015). Spielräume für Innovationen. Förderliche Strukturen in der kommunalen Integrationsarbeit [Scope for innovations. Enabling framework conditions in municipal integration practices]. Migration und Soziale Arbeit, 37(4), 353-361.

Bund, E., Gerhard, U., Hoelscher, M., \& Mildenberger, G. (2015). A methodological framework for measuring social innovation. Historical Social Research, 40(3), 48-78.

Çağlar, A. (2014). World migration report 2015. Geneva: International Organization for Migration. Retrieved from https://www.iom.int/sites/default/files/our work/ICP/MPR/WMR-2015-Background-PaperACaglar.pdf

Census (2011). Ergebnisse des Zensus 2011 [Census 2011 database]. Census. Retrieved from https:// ergebnisse.zensus2011.de

City of Heilbronn. (2014). City of Heilbronn's second integration report. Heilbronn: City of Heilbronn. Retrieved from https://www.heilbronn.de/ fileadmin/daten/stadtheilbronn/formulare/leben/ partizipation_integration_fluechtlinge/berichte/ Integrationsbericht_2014.pdf

Daamen, R., \& Doomernik, J. (2014). Local solutions for federal problems: Immigrant incorporation in Montgomery County, Maryland. Urban Geography, 35(4), 550-566.
DeFilippis, J., \& Faust, B. (2014). Immigration and community development in New York City. Urban Geography, 35(8), 1196-1214.

Dell'Agnese, E. (2013). The political challenge of relational territory. In D. Featherstone \& J. Painter (Eds.), Spatial politics: Essays for Doreen Massey (pp. 115-124). Malden, MA: John Wiley \& Sons.

Federal Employment Agency. (2015). Special evaluation: Labor market in figures. Nuremberg: Federal Employment Agency.

Federal Statistical Office. (2017). Population with a migrant background: Results of the microcensus 2015. Wiesbaden: Federal Statistical Office.

Filsinger, D. (2009). Entwicklung, Konzepte und Strategien der kommunalen Integrationspolitik [Development, concepts, and strategies of municipal integration politics]. In F. Gesemann \& R. Roth (Eds.), Lokale Integrationspolitik in der Einwanderungsgesellschaft [Local integration politics in the immigration society] (pp. 279-298). Wiesbaden: VS Verlag für Sozialwissenschaften.

Foroutan, N., Canan, C., Arnold, S., Schwarze, B., Beigang, S., \& Kalkum, D. (2014). Deutschland postmigrantisch I: Gesellschaft, Religion, Identität [Postmigrant Germany I: Society, religion, identity]. Berlin: Berlin Institute for Integration and Migration Research.

Gehring, P., \& Großmann, A. (2014). Constructing discursive differences: Towards a "logic" of cities. Historical Social Research, 39(2), 103-114.

Gerhard, U., Hoelscher, M., \& Wilson, D. (Eds.). (2017). Inequalities in creative cities: Issues, approaches, comparisons. New York, NY: Palgrave Macmillan.

German Federal Office for Migration and Refugees. (2020). Aktuelle Zahlen 12/2020 [Current figures 12/2020]. Nuremberg: German Federal Office for Migration and Refugees.

Glick Schiller, N. (2013). A comparative relative perspective on the relationships between migrants and cities. Urban Geography, 33(6), 879-903.

Glückler, J., Suddaby, R., \& Lenz, R. (2018). On the spatiality of institutions and knowledge. In J. Glückler, R. Suddaby, \& R. Lenz (Eds.), Knowledge and institutions (pp. 1-22). Berlin: Springer.

Gruber, M. (2010). Integrationspolitik in Kommunen: Herausforderungen, Chancen, Gestaltungsansätze [Integration policies in municipalities: Challenges, opportunities, approaches]. Vienna: Springer.

Hendriks, F. (2014). Understanding good urban governance: Essentials, shifts, and values. Urban Affairs Review, 50(4), 553-576.

Jonas, A. E. G., \& Ward, K. (2018). Spaces of circulation. In K. Ward, A.E.G. Jonas, B. Miller, \& D. Wilson (Eds.), The Routledge handbook on spaces of urban politics (pp. 389-392). London: Routledge.

Kuckarz, U. (2014). Qualitative Inhaltsanalyse: Methoden, Praxis, Computerunterstützung [Qualitative content analysis: Methods, practice, computer assis- 
tance]. Weinheim: Beltz Juventa.

Lake, R. W., \& Newman, K. (2002). Differential citizenship in the shadow state. Geo Journal, 58(2/3), 109-120.

Leitner, H., \& Strunk, C. (2014). Assembling insurgent citizenship: Immigrant advocacy struggles in the Washington DC metropolitan area. Urban Geography, 35(7), 943-964.

Marrow, H. B. (2009). Immigrant bureaucratic incorporation: The dual roles of professional missions and government policies. American Sociological Review, 74(5), 756-776.

Massey, D. (1993). Questions of locality. Geography, 78(2), 142-149.

Mutch, A. (2007). Reflexivity and the institutional entrepreneur: A historical exploration. Organization Studies, 28(7), 1123-1140.

Pott, A. (2018). Migrationsregime und ihre Räume [Migration regimes and their spaces]. In A. Pott, C. Rass, \& F. Wolff (Eds.), What is a migration regime? (pp. 107-135). Wiesbaden: Springer.

Pütz, R., \& Rodatz, M. (2013). Kommunale Integrationsund Vielfaltskonzepte im Neoliberalismus: Zur strategischen Steuerung von Integration in deutschen Großstädten [City strategies on diversity and integration under neoliberal conditions: Strategic management of integration in major German cities]. Geographische Zeitschrift, 101(3/4), 166-183.

Schammann, H. (2015). Wenn Variationen den Alltag bestimmen. Unterschiede lokaler Politikgestaltung in der Leistungsgewährung für Asylsuchende [When variations determine every-day life. Differences of local policy-making payment of benefits for asylum seekers]. Zeitschrift für Vergleichende Politikwissenschaft, 9(3), 161-182.

Scott, R. (2001). Institutions and organizations. Thousand Oaks, CA: Sage.

Shaw, S., Bagwell, S., \& Karmowska, J. (2004). Ethnoscapes as spectacle: Reimaging multicultural districts as new destinations for leisure and tourism consumption. Urban Studies, 41(10), 1983-2000.

State Office for Information and Technology of North
Rhine Westphalia. (2014). Core fiscal debts per capita 31.12.2013. North Rhine Westphalia: State Office for Information and Technology of North Rhine Westphalia.

Statistical Offices of the Federation and the Federal States. (2015). Regional database: Core fiscal debts of municipalities and municipality associations per capita 31.12.2013. Wiesbaden: Statistical Offices of the Federation and the Federal States.

United Nations. (2019). International migration 2019. New York, NY: United Nations. Retrieved from https://www.un.org/en/development/desa/ population/migration/publications/migrationreport/ docs/InternationalMigration2019_Report.pdf

van Winden, W. (2010). Knowledge and the European city. Tijdschrift Voor Economische En Sociale Geografie, 101(1), 100-106.

van Winden, W., van den Berg, L., \& Pol, P. (2007). European cities in the knowledge economy: Towards a typology. Urban Studies, 44(3), 525-549.

Walker, K. E. (2014). Immigration, local policy, and national identity in the suburban United States. Urban Geography, 35(4), 508-529.

Walker, K. E., \& Leitner, H. (2011). The variegated landscapes of local immigration policies in the United States. Urban Geography, 32(2), 156-178.

Wells, M. J. (2004). The grassroots reconfiguration of U.S. immigration policy. International Migration Review, 38(4), 1308-1347.

West, C. (2013). Integration zwischen Konformität, Interkulturalität, Transkulturalität? [Integration in between conformity, interculturality, transculturality?] In O. Schnur, P. Zakrzewski, \& M. Drilling (Eds.), Migrationsort Quartier. Zwischen Segregation, Integration und Interkultur [Place of migration district. In between segregation, integration, and interculture] (pp. 195-223). Wiesbaden: Springer.

Wiest, K. (2020). Ordinary places of postmigrant societies: Dealing with difference in West and East German neighbourhoods. Urban Planning, 5(3), 115-126.

\section{About the Authors}

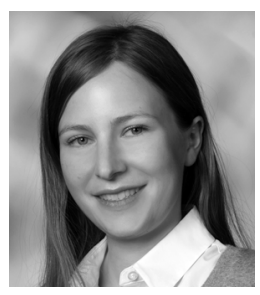

Eva Bund is a PhD Candidate at Heidelberg University and is working for the Department of International Affairs at the German Federal Office for Migration and Refugees (BAMF). Her research focuses on migration, integration, and urban and public sector innovation. At the BAMF she was involved in empirical studies on the life situation of refugees and ethnic German resettlers and later was head of President's office. Prior to this, she was a Research Associate at the Centre for Social Investment of Heidelberg University.

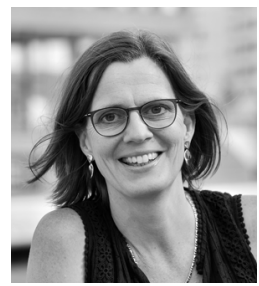

Ulrike Gerhard is a Professor of Urban Geography at the Institute of Geography at Heidelberg University. Her research examines how recent political, social, ecological, and economic restructuring shapes urban space. She is Head of the real-world lab "Urban Office: Sustainable Urban Development in the Knowledge-Based Society," and has edited and authored several books (e.g., Inequalities in Creative Cities, 2017; Die Stadt von morgen, 2020). She has broadly published in international journals such as Geographica Helvetica, Historical Social Research, and Geographische Zeitschrift. 